\title{
Circulation of porcine circovirus type 2 in pigs of different age groups in the Russian Federation
}

\author{
Larisa A. Neminuschaya*, Natalia K. Eremets, Tatyana A. Skotnikova, Igor V. Pavlenko, Vladimir I. Eremets, Evgenia V. \\ Markova, Valentina I. Klyukina, and Larisa S. Lyulkova
}

All-Russian Scientific Research and Technological Institute of Biological Industry, Moscow region, 141142, Russia

\begin{abstract}
The paper deals with the results of assessing the intensity of PCV2 (porcine circovirus type 2) circulation in pigs of different age groups on pig farms in the Russian Federation. Serum samples of 128 pigs of different age groups from two pig farms in the Russian Federation were studied. As a result, specific antibodies to PCV2 were detected that proves virus circulation. Average titer of serum antibodies was 1:2020 for weaning piglets, 40 d.a. (days of age), in prenursery piglets of the age of 20 days - 1:3120; in replacement gilts of the age of 175 days - 1: 5124; in feeding pigs of the age of 180 days - 1:5300. In female pigs, the percentage of seroprevalence was $95 \%$. With advancing ageing of pigs, the level of antibody titer to PCV2 was increasing that proves the animals were infected after the decrease of colostral antibody level below protective one.
\end{abstract}

\section{Introduction}

Porcine circovirus infection in pigs is widely spread in many countries of the world with the developed commercial pig production, and it causes considerable economical damage conditioned by high morbidity and mortality, decrease in productivity and reproduction properties of the animals $[1,2,3]$. Porcine PCV2 belongs to the family Circoviridae, has a small one-spiral annular DNA molecule, formed by1766-1768 nucleotides. Porcine circovirus type 2 , first isolated in 1991 , is the principal reason of the clinical manifestation of postweaning multisystemic wasting syndrome (PMWS) $[4,5,6]$. Other syndromes in pigs, with which the contamination with PCV2 is connected, include dermatitis and nephropathy syndrome in piglets, shaking of newborn pigs, reproductive failure syndrome, immune deficiency, subacute/chronic proliferative and necrotizing pneumonia $[7,8,9]$. The occurrence of the diseases is upregulated by the development of mixed infections of PCV2 with other pathogens of viral and bacterial nature: Porcine Reproductive and Respiratory Syndrome, Porcine Parvovirus, Haemophilus parasuis, Mycoplasma hyrhinis, Mycoplasma hyopneumoniae, Pasteurella multocida, etc. PCV2 circulation on the farm decreases the efficiency of vaccination against other pathogens $[10,11]$. The source of infection is sick and symptom-free infected pigs of different age groups that shed PCV2 via feces, urine, saliva, milk, eye and nasal secretions [12,13]. Virus persistence in DCs is a mechanism of agent propagation and transfer in the population of susceptible animals. The infection control is based on rapid and reliable diagnostics. PCV2 should be complex and based on epizootological, clinical, pathoanatomical and laboratory (serologic, microscopic, virologic and molecular genetic) study methods. For PCV2 infection diagnostics, study methods aimed at the detection of an agent and antibodies to it are used. Such methods include different variants of PCR and enzyme immunoassay (EIA) [14].

Timely detection of the agent and the specific prevention of circovirus infection in pigs are crucial for recreation of farms, and the use of efficient vaccines against PCV2 infection is the principal means of circovirus infection control and the prevention of concomitant diseases because the PCV2 circulation in the pig population causes considerable economical damage due to negative impact on the key immunecompetent organs of pigs and prevents from creating the reliable long-term post-vaccination immunity after using any vaccines against infection diseases in pigs $[15,16]$. The ability of vaccines against porcine circovirus infection to prevent viremia and to increase the production figures serves as their efficiency criterion.

The aim of the study is to assess the intensity of PCV2 circulation in pigs of different age groups on pig farms in the Russian Federation.

\section{Materials and Methods}

The study was carried out in the Department of Molecular Biology and Virology of FSBSI "AllRussian Research and Technological Institute for Biological Industry" (FSBSI “ARRTIBI”). 128 serum samples from piglets of the age of $30(n=38), 60(n=20)$, $100(\mathrm{n}=10), 120(\mathrm{n}=10), 150(\mathrm{n}=10)$ and 175-216 $(\mathrm{n}=40)$ days from two farms were tested under bilateral agreements. Not-in-pigs and morbidity in prenursery

\footnotetext{
"Corresponding author: Smolentsev82@mail.ru
} 


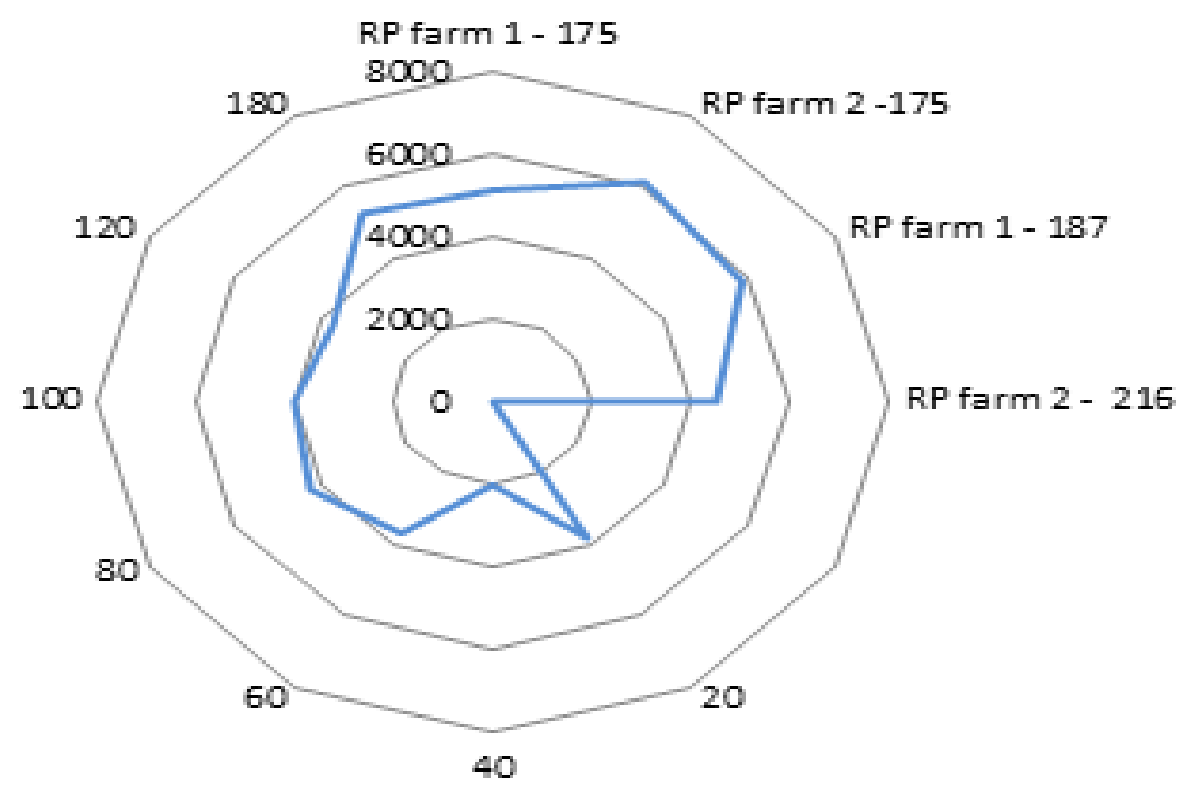

Fig. 1. The block diagram of the wastewater treatment process produced in the Centre Treatment Oil ROM, Hassi Messaoud, Algeria (RP farm 1 - 175 - replacement gilts of the age of 175 days on farm 1; RP farm 1 - 187 - replacement gilts of the age of 187 days on farm $1 ; 20$ - prenursery pigs of the age of 20 days; 40,60,80,100,120,180 - feeding pigs of the age of 40, 60, $80,100,120,180$ days, respectively).

piglets were observed on farms. Animals were not vaccinated earlier against the porcine circovirus infection. For detecting viremia in serum of the animals, the quantitative "Set for porcine circovirus type 2 detection by real-time PCR", produced by "BioChek", was used. To evaluate specific antibody titer, "EIA test for detection of antibodies to PCV2", produced by "BioChek", was used.

Serum samples were stored unpreserved in the frozen state $\left(\right.$ at $-70^{\circ} \mathrm{C}$ ), all of them were tested simultaneously for specific antibodies to PCV2 by EIA with the use of the commercial set "EIA test for detection of antibodies to porcine circovirus PCV2" (Catalog number "SK105", "BioChek", the Netherlands) in accordance with the producer's instruction. Initial dilution of test serum was $1: 100$. The reaction results were registered on the spectrophotometer "BioTek" (produced in the USA). The results of the presence of antibodies to PCV2 were registered under the assessment of the $\mathrm{S} / \mathrm{P}$ ratio (test sample/positive ratio) with the wavelength of $405 \mathrm{~nm}$ used at spectrophotometry. Samples with the $\mathrm{S} / \mathrm{P}$ ratio equaling or exceeding 0.500 contained antibodies to PCV2 and were accepted as positive.

\section{Results and Discussion}

With EIA method, specific antibodies to PCV2 were detected in serum samples from 88 pigs of different ages. An average titer of serum antibodies in prenursery piglets of the age of 20 days was 3120; in replacement gilts of the age of 175 days - 5124; in feeding pigs of the age of 180 days - 5300. High titer of antibodies was detected in serum of young replacement gilts on all tested farms - values of antibody titer were from 4393 to 6175 at $100 \%$ seroprevalence. In female pigs, the level of seroprevalence was $95 \%$, in 40 -day-old weaning piglets, minimal average values of antibody titer was 2020 at $60 \%$ seroprevalence. With advancing ageing, the increase in the level of specific antibody titer to PCV2 was detected that proves the infection of the animals after the decrease in colostral antibody titer. The dynamics of specific antibody titer to PCV2 in pigs of different age is shown in Figure 1.

Thus, in serology study with EIA method, PCV2 circulation on farms tested was detected. In randomly sampled female pigs, after the animal yield, livability and average daily gain of piglets were assessed and further compared to the level of antibodies and viremia in serum. The data of the study of the number of copies of DNA virus and antibody titer to PCV2 (by quantitative real-time PCR and EIA) in littermate pigs' serum (the number of littermate pigs was 8 ) are shown in Figure 2. While laboratory analyses were being conducted, littermate pigs No.1 and 2 died. In case of high viral load $>10^{5}$ copies of DNA virus $/ \mathrm{cm}^{3}$ in serum, we recommended the preventive immunization with regard of the period of viremia and the clinical manifestation of circovirus infection at the pig's age of 21 to 40 days.

One of the most important indicators that is tracked at the control of circovirus infection in the herd is the viremia level control. Viremia level (number of virus DNA copies per $\mathrm{cm}^{3}$ ) in serum or in tissues of a piglet is 


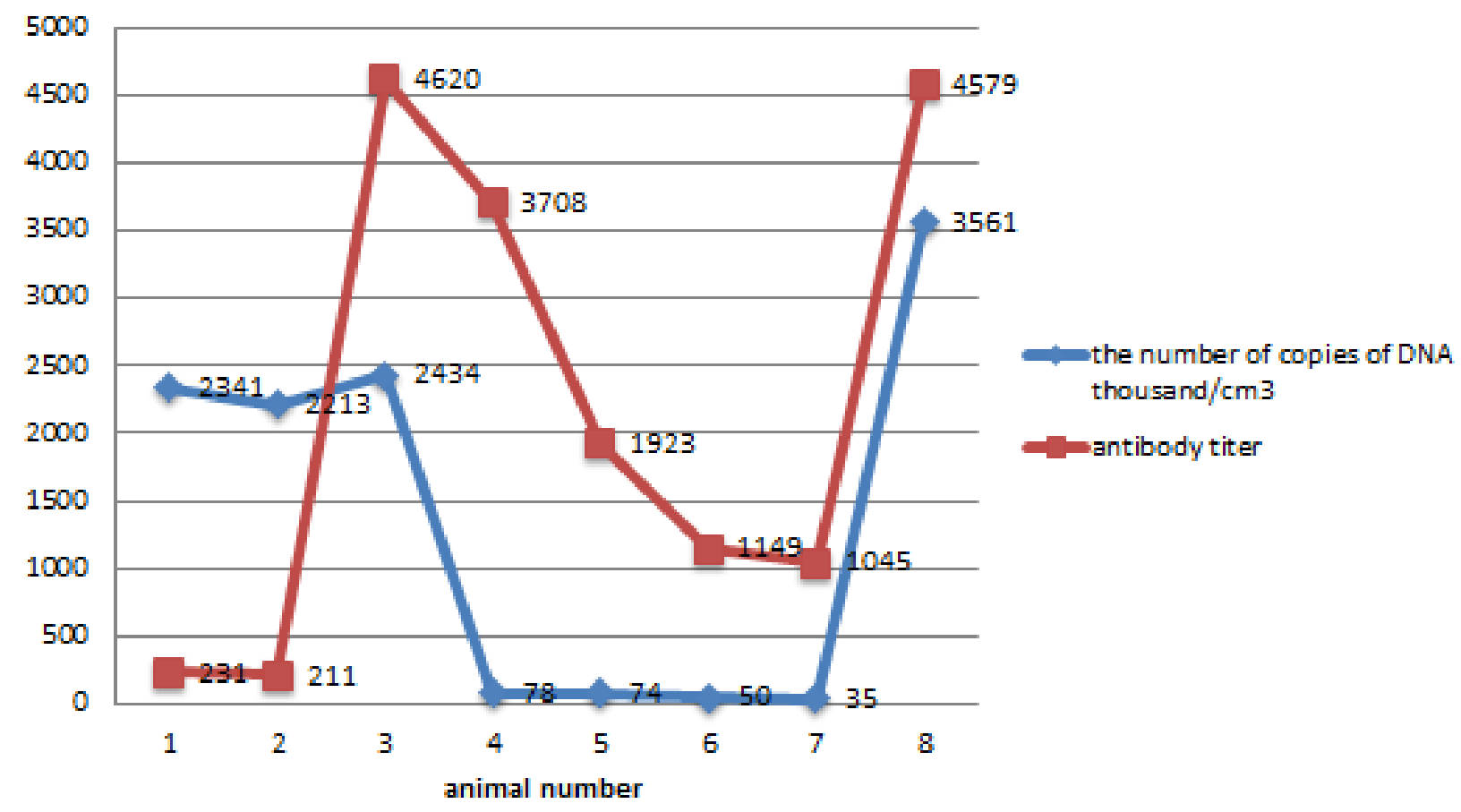

Fig. 2. The number of copies of DNA and antibody titer to PCV2 in littermate pigs' serum.

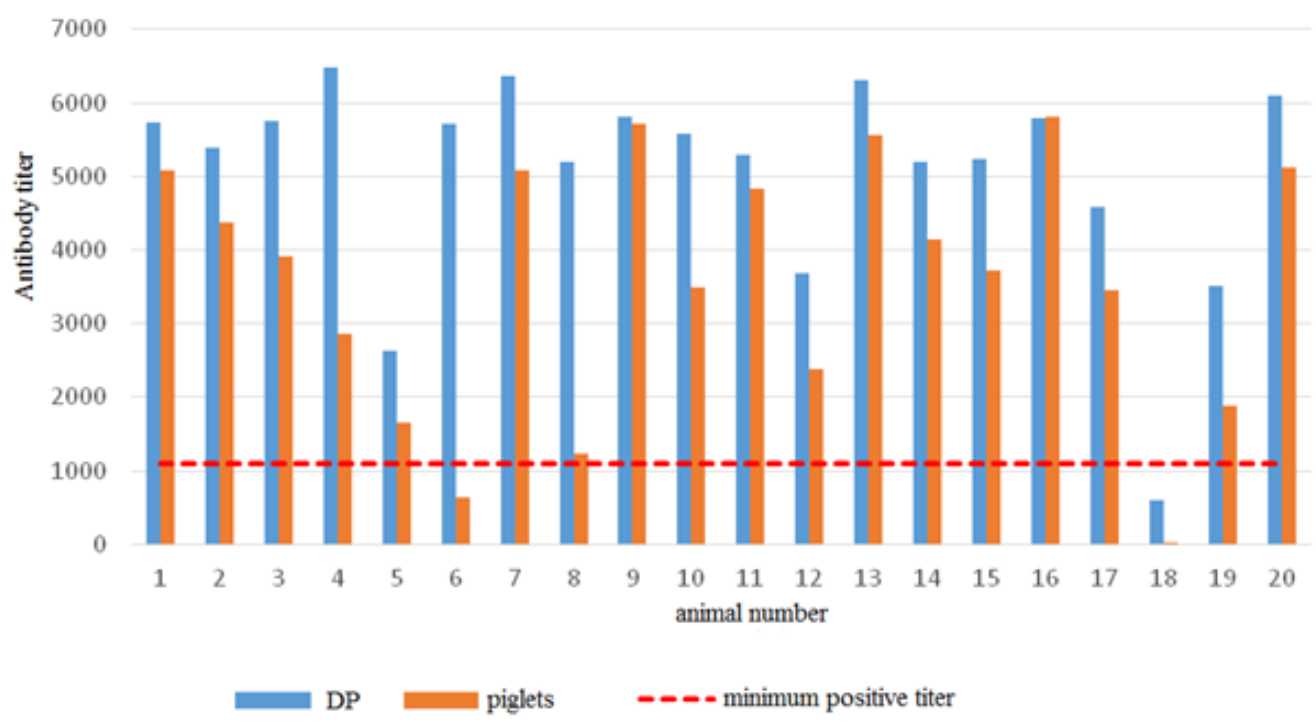

Fig. 3. Specific antibody titer to PCV2 in female pigs and piglets (offspring).

used as a criterion for dividing PCV2 of infected pigs into those subclinically infected and PCV2-positive. Viral load quantitation can also be used as a parameter for assessing the anti-PCV2 vaccine efficiency: viremia decrease correlates with the presence of PCV2neutralizing antibodies (NA) and interferon- $\gamma$-secreting cells (IFN- $\gamma$-SCs).

Figure 3 shows the results of detecting the specific antibody titer to PCV2 in female pigs and their offspring. On some Russian farms, PCV2 infection is latent and without any clinical signs (asymptomatically/subclinically). In such cases, high level of virus-neutralizing antibodies and low viral load are registered in serum.

For quantitation of PCV2 genome in serum and tissues, real-time PCR is used; in the EU countries, it is even recommended for use under production conditions to forecast the dynamics of the infection and epizootic processes at circovirus infection. The level of tissue damage, clinical manifestation of PCV2 and its course depends on the concentration of PCV2 genome in the certain tissues. $10^{7}$ and more copies of PCV2 genome per $1 \mathrm{~cm}^{3}$ of serum corresponds to the unfavorable forecast about the course of the circovirus infection, the clinical state, and the level of tissue damage. The 
concentration of PCV2 genome of less than $10^{6}$ per 1 $\mathrm{cm}^{3}$ proves the virus infection; concentration of copies at the level of $10^{6}$ per $1 \mathrm{~cm}^{3}$ indicates that a pig has circovirus infection, and the concentration of $10^{7}$ DNA copies and more per $1 \mathrm{~cm}^{3}$ shows the acute form of the disease.

\section{Conclusion}

While studying the serum of pigs by EIA with the use of diagnostic sets "Biochek" that help detect quantitative indicators in serum: number of virus DNA copies per $\mathrm{cm}^{3}$ and specific antibody titer to PCV2, PCV2 circulation in pigs of different age groups was detected. Dynamics of specific antibodies had the classic pattern: high and homogeneous immunity in young replacement gilts. Seroprevalence increase, proportional to the increase of the age of piglets, caused by their contamination against the background of colostral immunity decrease was identified. Probably, PCV2 infection occurred at the age of 30-60 days. In case of high viral load $\left(>10^{5}\right.$ copies $/ \mathrm{ml}$ in serum), the preventive immunization with commercial vaccines against circovirus infection was recommended.

\section{References}

[1] B. Bebe, J. Udo, G.J. Rowlands, W. Thorpe, Livestock Production Sci., 82 (2003).

[2] J.B.Cole, D.J. Null, J. Dairy Sci., 92, 5 (2009).

[3] T.A. Cooper, G.R.Wiggans, D.J.Null, J.L.Hutchison, J. Cole, J. Dairy Sci., 97 (2014).

[4] E.Hare, H.D.Norman, J.R. Wright, J. Dairy Sci., 89 (2006).

[5] S.Loker, F.Miglior, J.Bohmanova, J. Jamrozik, L.Schaeffer,J. Dairy Sci., 92 (2009).

[6] N. Lopez-Villalobos, D.J.Garrick, C.W. Holmes, H.T. Blair, R.J.Spelman,J. Dairy Sci., 83 (2000).

[7] E.J. Rincon, E.C.Schermerhorn, R.E. Mc Dowell, B.T. Mc, J. Dairy Sci., 65 (1982).

[8] A.Sewalem, G.J.Kistemaker, V.Ducrocq, B.J. Van Doormaal, J. Dairy Sci., 88 (2005).

[9] A.Sewalem, G.J.Kistemaker, F.Miglior, B.J. Van Doormaal, J. Dairy Sci., 89 (2006).

[10] G.R.Wiggans, I.Misztal, L.D. Van Vleck, J. Dairy Sci., 71 (1988).

[11] S.E.Ilyasovich, T.A. Mikhailovna, S.V.Rasimovich,S.S. Yurievich, S.F.Akhmadullovich,P.K.Khristoforovich, T.M.Yakovlevich, RJPBCS, 7, 4 (2016).

[12] S.E.Anatolievna,P.O.Yurievch, T.E.Vasilevna,K.T. Viktorovna, S.E. Gennadievna, S.S. Yurievich, Research RJPBCS, 7(3)(2016).

[13] P.K.Khristoforovich, K.I. Ravilevich, S.V. Rasimovich, T.M. Yakovlevich, T.A. Mikhailovna, S.F. Akhmadullovich, S.S. Yurievich, RJPBCS, 7, 4 (2016).

[14] H.F. Brabander, H. Noppe, K. Verheyden, Residue analysis: Future trends from a historical perspective. Chromatography, 12 (2009).
[15] P.A. Carrasco, T.S. Casado, C.A. Segura, G.A. Fernández, J.Chromatogr. A., 9 (2008).

[16] R.M. Chilumuru, C.A. Lakkineni, B.S. Chandra,J. Biological Sci., 4, 5 (2015). 